\title{
MUSCADINE GRAPE BREEDING
}

\author{
The Native Grape of the Southeastern United States Has Been Hybridized \\ Successfully with the European Grape-Valuable Self-fertile \\ Varieties Produced.-A New Possibility for the \\ Cut-over Pine Lands of the South
}

Charles Dearing

Office of Horticulture and Pomology, Bureau of Plant Industry, Washington, $D . C$.

$\mathrm{I}^{\mathrm{T}}$ $T$ IS a well-recognized fact that cultivated grape varieties derived from the species native to a particular locality thrive under the environmental conditions existing there. The grape varieties best adapted to the hot and more or less arid portions ant the higher elevations of the South Central States are those produced by T. V. Munson of Texas, Herman Jaeger of Missouri, and others, from the summer grape, $V$. aestivalis, of the southern Great Plains area. The best grape varieties for the northeastern United States are those, such as Concord, which have been obtained from the northeastern fox grape, $V$. labrusca. The varieties of the river-bank grape, $V$. riparia, thrive in alluvial districts. In like manner the Muscadine ${ }^{\prime}$ grapes, $V$. rotundifolia and $V$. munsoniana, are the proper species for the Southeast because that is their native home. For this reason, in endeavoring to foster grape culture in the Coastal Plain, Piedmont, and Gulf sections of the southeastern United States, the U. S. Department of Agriculture has endeavored to ameliorate the native Muscadine grape rather than to introduce varieties of species known to be ill adapted to the climatic and other environmental conditions.

In their native habitat the Muscadines thrive and produce abundant crops. They do well on lands where other fruits do not succeed, flourishing in poorly drained soils, and warm, humid atmospheric conditions which are detrimental to other species of grape. They have been cultivated for a great many years in the Southeast, but little effort was made until recently to bring about improvement through breeding. Even at the present time the standard commercial varieties are less than six in number and all named varieties are of the $V$. rotundifolia species. These varieties have been named, propagated and disseminated merely because they represented the best that occurred in Nature. Even so, however, they are good grapes, highly prized by the people of the South, who grow them extensively for wine, table, and culinary purposes.

In addition to being native to the Southeast and adapted to soil and climatic conditions there, the Muscadines further qualify as the best grapes for that section by having such desirable characteristics as:

1. Vigorous growth habit.

2. High productiveness.

3. Distinctive and agreeable flavor.

4. Large berries.

5. Late and long blooming period, insuring regular crops.

6. Resistance to diseases and insects.

7. Marked ability to withstand adverse conditions, though responsive to good care.

1 The Muscadine grapes, which include two botanical species, Vitis roturdifolia and Vitis munsoniana, are one group of the grape genus. This group is called Muscadinia. The other group, comprising the other native grape species and the European grape (Vilis vinifera), is called Euvitis. The Muscadiria is distinct from Euvitis botanically in that it has closely adherent bark on the branches, continuous pith through the nodes, unforked tendrils, and flattened seeds with transverse wrinkles on both sides. 


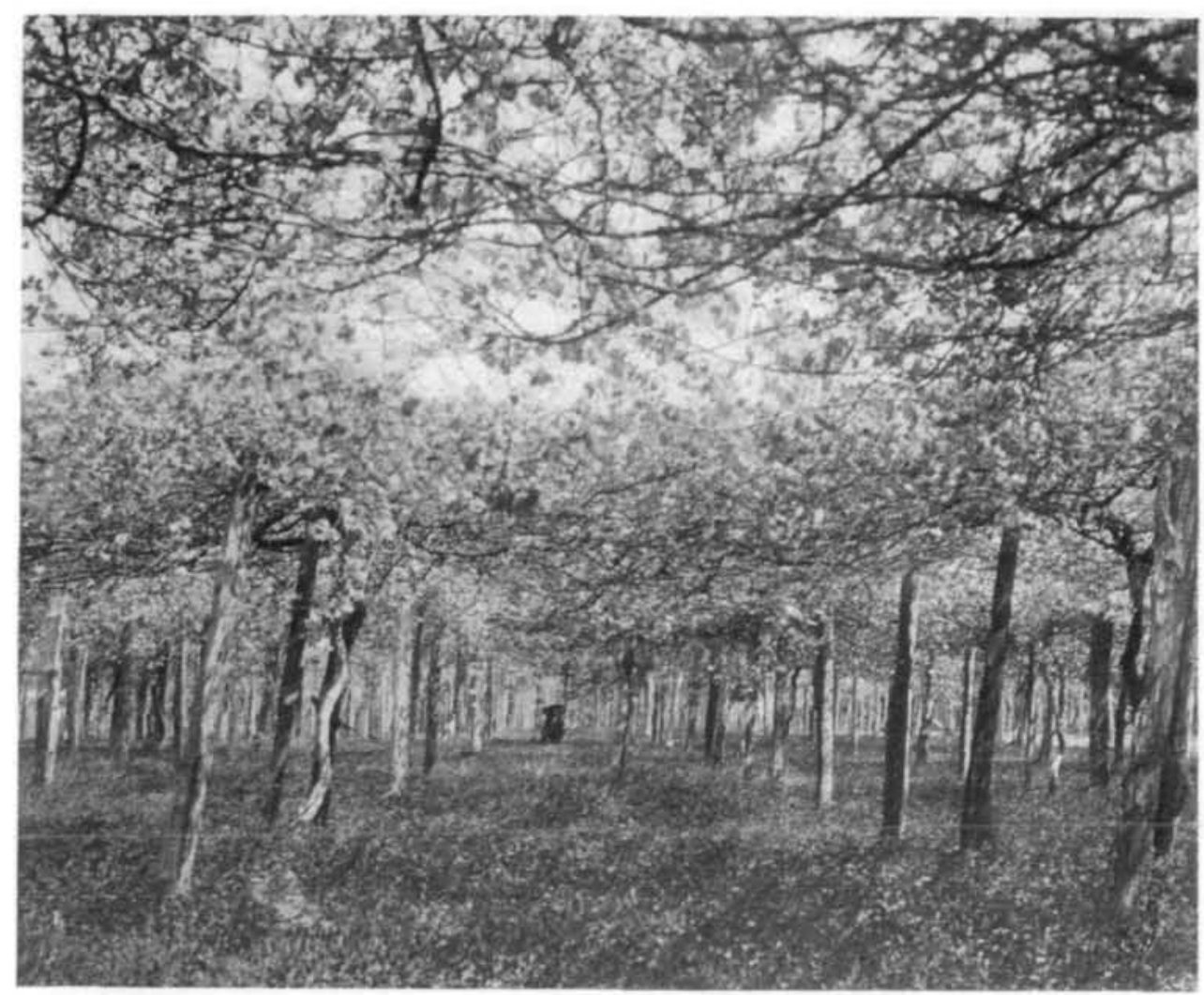

A VINEYARD OF MUSCADINE GRAPES

The ground crop is crimson clover. Sometimes sheep are pastured on it, which makes threestory agriculture. The Muscadine grape is a favorite in the southeastern United States where it is native, but offers much room for improvement. Unlike the ordinary grape the Muscadine has been trained high on overhead trellises. (Fig. 10.)

8. Ability to produce profitable crops for 100 or more years.

With such creditable characters, though still a practically untamed branch of the grape family, the Muscadines seemed to offer unusual opportunity for improvement. On the other hand, there were certain difficulties in the way of improvement which the Department recognized from the beginning. For instance, there was not a single known self-fertile variety among the Muscadines, thus necessitating the use of a wild male vine of unknown fruit character in every cross. The only available female varieties were those which had been brought under cultivation and more or less disseminated by persons finding them in the woods and recognizing them as superior to the average wild grape. Nothing was known about the parentage of these varieties and as their distribution had been more or less limited to the vicinity in which they originated their real varietal value had not been established. There were no improved male vines and their need had not been realized, as the importance of providing cross-pollination facilities was unknown.

Such were the conditions when the U. S. Department of Agriculture undertook to improve the Muscadine grape in those ways in which improvement seemed desirable and possible. Apparently these were:

1. Production of improved male vines.

2. Production of self-fertile varieties.

3 . Greater productiveness.

4. Increased size of fruit cluster. 


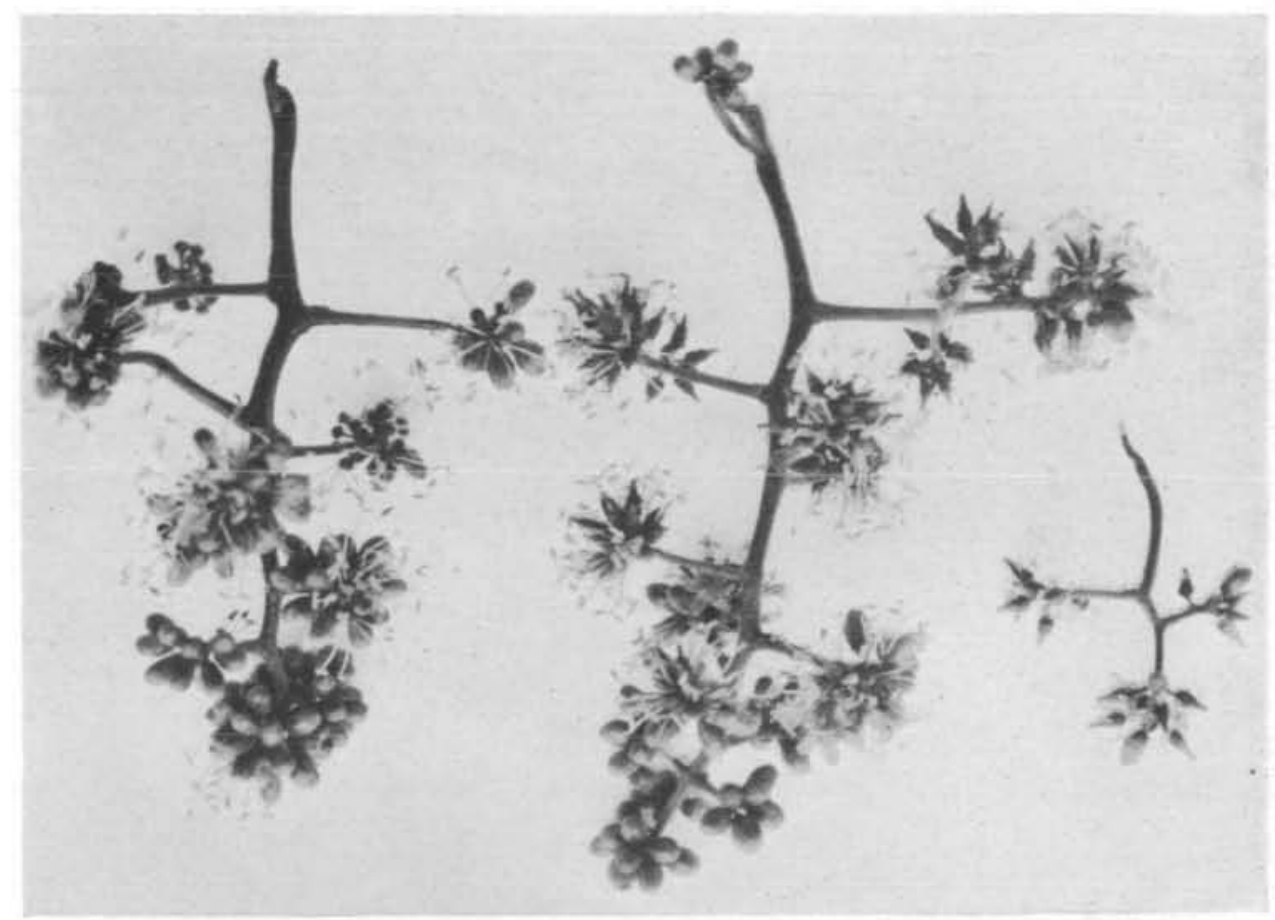

TYPES OF MUSCADINE GRAPE BLOOM-CLUSTERS

The small cluster on right is typical of the female or, more properly, imperfect hermaphrodite type. All the standard commercial varieties are of this type and the cluster photographed is of the leading variety, Scuppernong. The cluster on left is a typical male or staminate vine cluster. The middle cluster is typical of the new perfect-flowered, self-fertile hermaphrodite type produced by the U. S. Department of Agriculture. Note that it resembles the male cluster in size and shape rather than the female cluster, and that it has erect stamens surrounding a normal pistil in each blossom while the male cluster has no pistils and the female cluster has only short, rudimentary stamens. Photograph one and one-half times natural size. (Fig. 11.)

\section{Better berry adherence.}

6. Higher sugar and lower acid content.

7. Better pulp quality.

8. Decreased size of seed.

9. Thinner skin of berries.

10. More uniform ripening.

The early surveys showed that the main problem of breeding would be to bring together the desirable characters already present in the two species constituting the Muscadine group, especially $V$. rotundifolia, though it also seemed necessary to go outside of the group for certain other improvements, such as marked alteration of the sugaracid ratio. The efforts of the Department, therefore, have been, first, to combine and augment in a few varieties the desirable characters now scattered among many varieties of the Muscadines, by cross-breeding and selection work within the species; and, second, to bring about additional improvement by hybridizing with other grape species.

\section{RESULTS PROM INTERCROSSING}

In practically every way in which improvement seemed desirable as already indicated, improvement has been secured. Among the more than 5,400 seedling vines produced by the Department there are selected individuals which represent progress toward certain ones of our stated goals and the best of these are being multiplied and thoroughly tested with a view to introducing them eventually as named varieties 


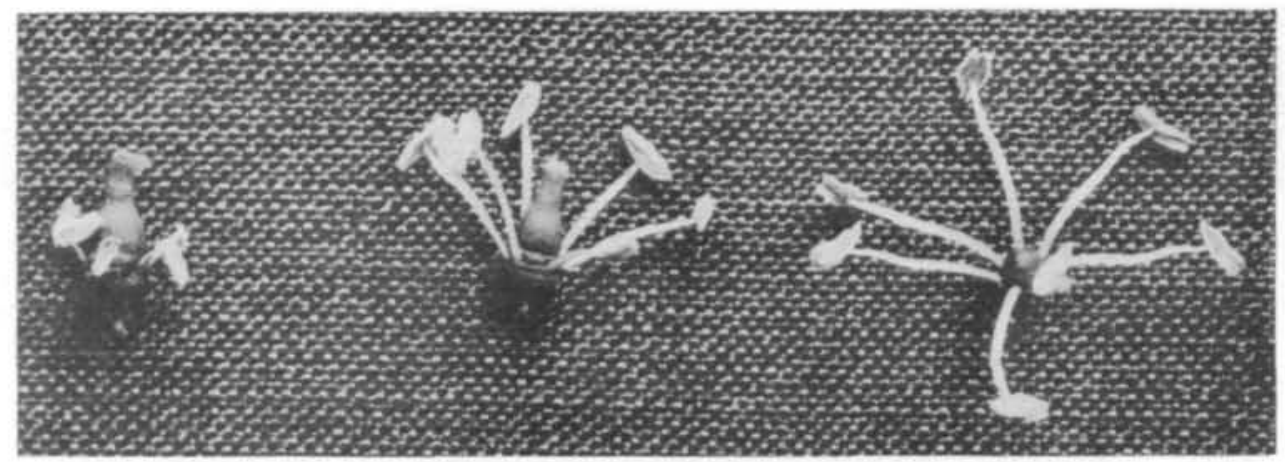

\section{TYPES OF MUSCADINE GRAPE BLOSSOMS}

At the left is the imperfect hermaphrodite blossom-the so-called female. The male or staminate blossom is at the right, while the new, perfect type produced by the U.S. Department of Agriculture is shown in the center. It will be noted that this new type is a selffertile hermaphrodite, which produces pollen for its own flowers. Its introduction will do away with the necessity of giving space in a vineyard to male "drone" vines that yield pollen but no fruit. The flowers are photographed about three times natural size, on a background of very fine silk. (Fig. 12.)

recommended for planting. Many of these varieties are improved in more than one character.

Intercrossing has been extensively practiced from year to year, the best available fruiting vines being pollinated by the best male seedlings of desirable groups. This work has neccssitated most intimate and careful study of the thousands of scedlings produced, in order to be able to select parents intelligently. Certain male vines have become known by their behavior in cross-breeding just as the fruiting seedlings are known by the fruit characters they possess and transmit.

\section{Production of Improved Male Vines}

One of the first results, thereforc, from cross-breeding operations has been the obtaining of certain male vines, selected seedlings, which are improved varieties to the extent that they transmit desirable rather than undesirable characters and because they have been selected for vigor, freedom from disease and insect attacks, profuseness of bloom, long period of bloom, and proper time for bloom (i. e., simultaneous with fruiting varieties to be pollinated). These better male vines have, where conditions warranted, already been distributed to grape growers along with fruiting vines to be tested coöperatively in representative sections of the Muscadine territory.

\section{Production of Self-fertile Varieties}

Undoubtedly the most important result of the department's work is the production of self-fertile varieties. It should be emphasized that at the time these investigations were undertaken, there was not such a thing as a selffertile Muscadine grape. All the fruiting varieties were self-sterile and dependent on insects to bring fertile pollen from the wild male muscadines. The Department now has a large collection of self-fertile varieties.

The value of these self-fertile varieties is evident. (a) They are of inestimably great value in breeding work in that they afford for the first time the opportunity to intercross within the species without using as one parent a variety of unknown fruiting qualities (male vine). We can now breed directly for a combination of the desirable characters found in the fruiting varieties of $V$. rotundifolia. (b) They afford directly a cluster of increased size (a breeding object) in that the self-fertile varieties are the result of perfecting the largeclustered male type blossoms rather than the small-clustered female type blossoms. (c) They afford greater productiveness in that they are able to set 


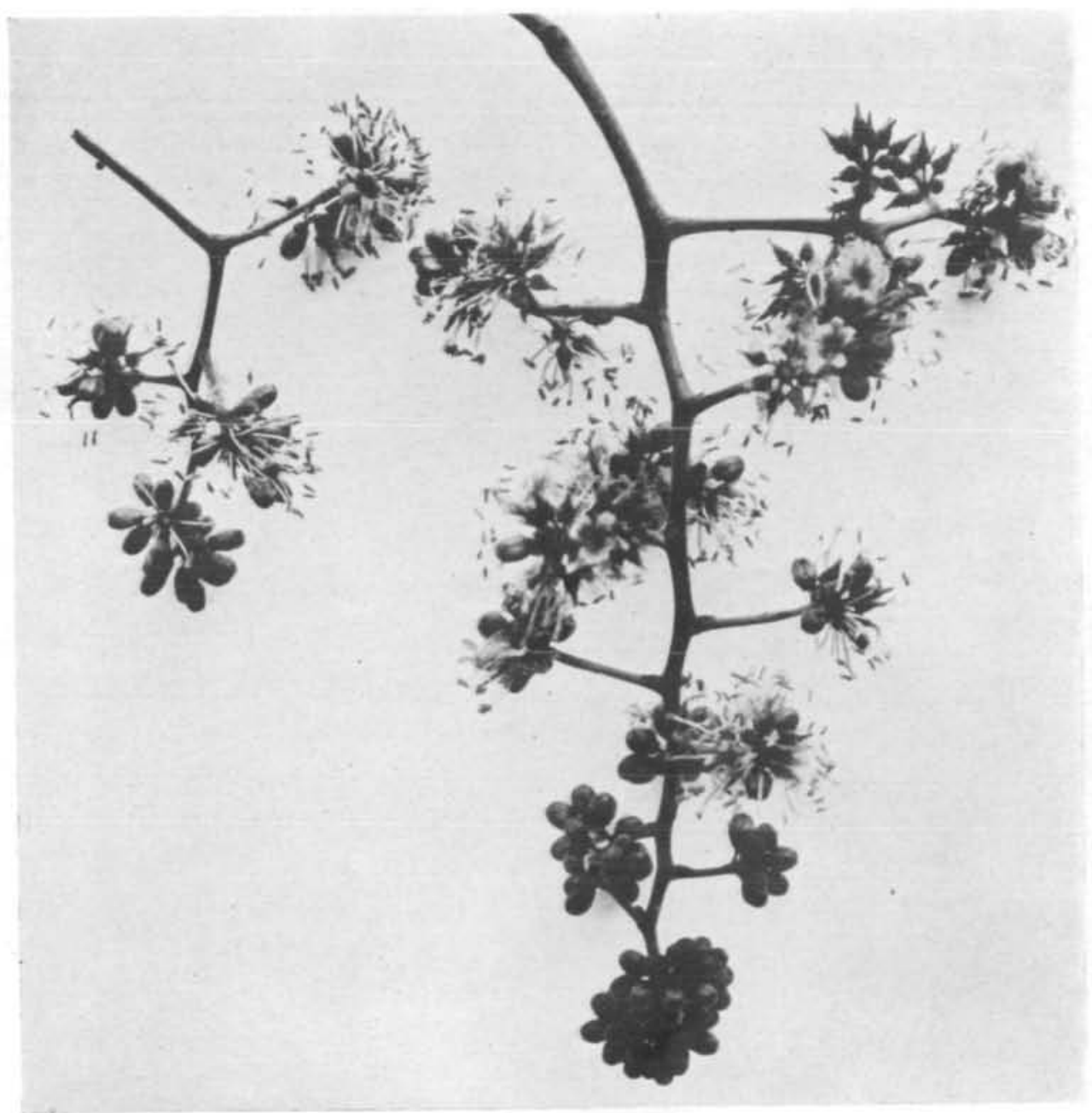

\section{BLOOM-CLUSTERS OF TWO HERMAPHRODITE MUSCADINE GRAPES}

At the left is a cluster from the one of the original hermaphrodites, known as $\mathrm{H} 2$, and on the right a cluster from $\mathrm{H} 1$, the other original hermaphrodite. The good size and proportions of the latter cluster are particularly noteworthy. Photograph about natural size. (Fig. 13.)

as berries from 25 to 50 per cent of the bloom huds, whereas the standard but self-sterile variety Scuppernong, for example, has set at Willard, N. C., under the best natural conditions less than $12 \%$ of the bloom buds annually for the last six years, owing to the fact that it must rely on insect crosspollination. (d) The new self-fertile varieties afford opportunity for greater vineyard production as well as vine production, for they can be planted in place of nonproductive male vines as pollinators for female varieties (morphologically imperfect hermaphrodites). The production of a self-fertile Muscadine grape means the production of a new type of Muscadine grape; one having a new type of bloom which is at once male and female and designated as perfect or hermaphroditic. This is so important to the industry that a rather full statement seems warranted here in order to show just what has been done.

The Department began its breeding work in 1907. The crosses that year 
were made chiefly in a commercial vineyard at New Smyrna, Fla., which contained the largest collection of varieties then in existence and was surrounded by quantities of native vines of $V$. munsoniana and $V$. rotundifolia, the two species constituting the Muscadinia group. In the same year, following the Florida work, other crosses were made at several places in Georgia, South Carolina, and North Carolina. where desirable material had been located. The seedlings resulting from this work were propagated in Washington and planted in the experiment vineyard at Willard, N. C., as the first seedling vineyard. Later when these seedling vines began to fruit and bloom, two of them were found to be true hermaphrodites, perfect-flowered, and self-fertile, whereas the other seedlings and all other Muscadine grapes were either staminate or pistillate. 2 The two original true hermaphrodites will be designated as $\mathrm{H} 1$ and $\mathrm{H} 2$ in the following discussion. $\mathrm{H} 1$ was the result of a cross at New Smyrna, Fla., between the standard female variety Eden and a wild, dark type, male, $V$. munsoniana vine. H2 was the result of a cross at Medoc Vineyard, Enfield, N. C., between the standard female variety Scuppernong and a light type male vine. $^{3}$ A large number of the seedlings were of the same parentage as the two hermaphrodites but male or female, like other Muscadines. From the two original hermaphrodites other hermaphrodites have been produced, but the Department has failed as yet to produce a third hermaphrodite of distinct parentage. ${ }^{4}$
Of the two original hermaphrodite seedlings, $\mathrm{H} 1$ is $V$. munsoniana in type, while $\mathrm{H} 2$ is entirely $V$. rotundifolia. The former has small black berries in relatively large clusters while the latter has large light colored berries resembling Scuppernong fruit, though not equal to Scuppernong in quality. The self-fertility of the latter is more pronounced.

Having produced the two original hermaphrodites, the next step was to multiply the type and to transmit the hermaphroditic character to other seedlings. $\mathrm{H} 1$ produced a little bloom in 1911. In addition to using this to test the seedling itself (i. $\varepsilon$., its pollen, pistils, and fruit), sufficient bloom was secured to pollinate two clusters of Eden, its female parent. This cross yielded two fruit clusters, one of eight berries and one of twenty-two berries, from which 154 seeds were secured. From these, fifty-four seedlings are now living and fruiting. Thirty of these (over $55 \%$ ) are hermaphrodites and the rest females. Apparently the seedlings which in a normal Muscadine cross would be males are in this case hermaphrodites, or, figuratively, pistils have been inserted in the staminate blossoms making true hermaphrodite blossoms. These seedlings are as a group intermediate between their parents. The best are very prolific, largeclustered, with average-size black berries of good vinous flavor and good quality. They are closely similar and fully equal to Eden and in addition have the hermaphrodite character. The better representatives are being used as parents in the breeding investigations.

After being used in 1911, H1 was

The lower type designated as pistillate or female is morphologically really an imperfect hermaphrodite having rudimentary stamens. There is no true pistillate type of bloom among the Muscadine grapes. The imperfect hermaphrodite bloom, however, behaves as a pistillate rather than as a hermaphrodite.

Male and fruiting vines of the Muscadines are of two types, light and dark, and this color character of the vine is correlated with the color of the fruit. Vines having reddish veins, young tendrils, and growing tips produce dark fruit (pink, red, purple, or black), while vines with light yellowish-green growing tips produce light fruit (yellow, bronze, pearly, or green). The males are classed likewise as indicated by their progeny.

- Since this paper was written the third hermaphrodite of distinct parentage has been produced. As it began blooming only recently and has not yet fruited, further reference to it is omitted. It is a vigorous vine of the light type and has set fruit rendily under bags. Its pollen germinates vigorously in sugar solution. It has been successfully used to pollinate standard varieties and other hermaphrodites and it has been successfully pollinated with pollen from male and from other hermaphrodite vines. It is the result of a cross in 1913 between two seedling vines in the Muscadine Grape Experiment Vineyard at Willard, N. C. 


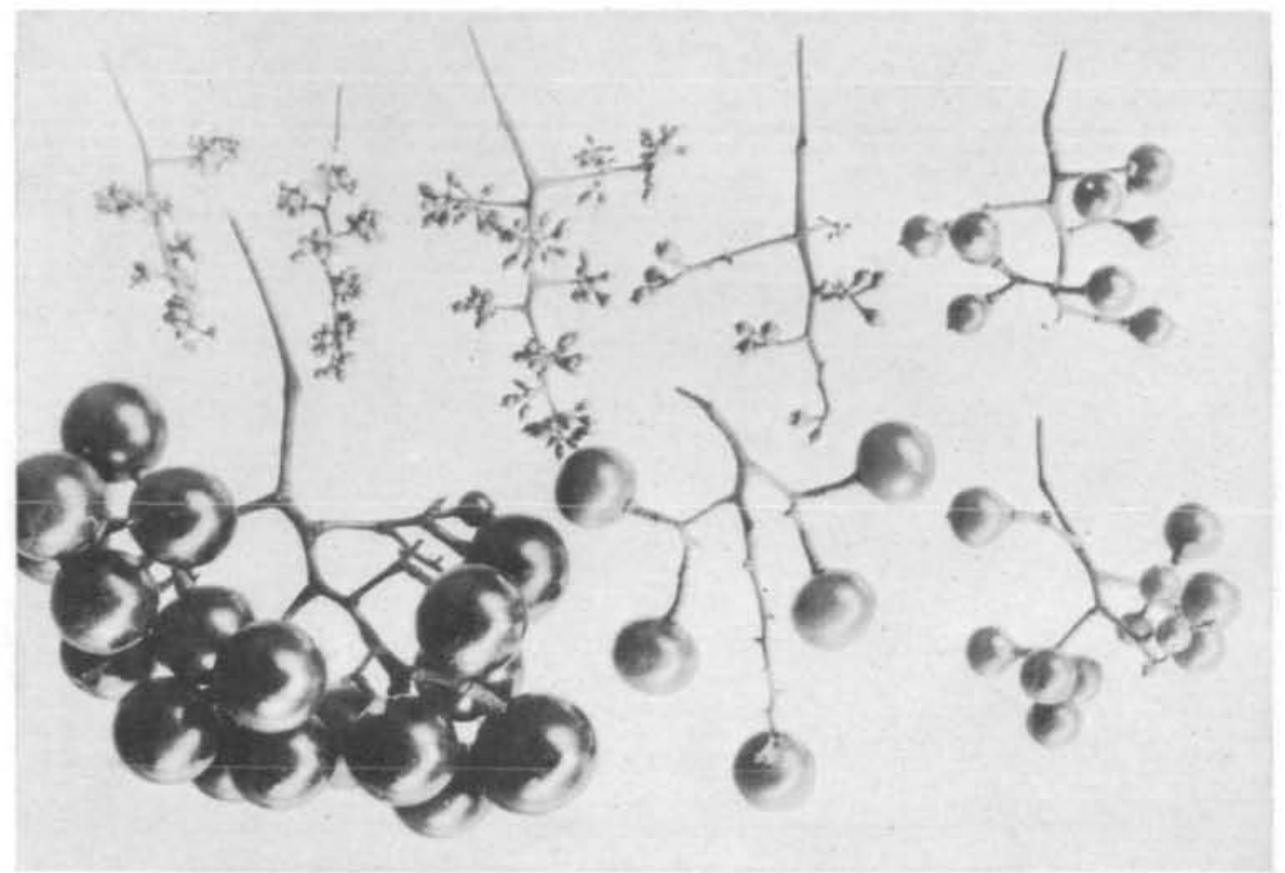

\section{FLOWERS, GREEN CLUSTERS AND RIPE GRAPES}

Clusters picked on October 2 from one of the original true hermaphrodite vines, H1. They show the berry characters, and also show that fruit of all sizes is to be found at one time, from the ripe berry to the blossom. This extends the season of the fruit advantageously. Four-fifths natural size. (Fig. 14.)

killed to the ground during the severe winter of 1911-12, but sprouted and has not since shown injury. Vines propagated by cuttings from it are now fruiting in the varietal collection.

In 1912 sufficient pollen of $\mathrm{H} 2$ was available to permit limited crossing, from which one Scuppernong cross, seven James crosses, and five selfed crosses are now fruiting. The seedling of Scuppernong parentage is a female, but subsequent crosses have shown that this was merely chance. Had there been more seedlings produced, some would undoubtedly have been hermaphrodites. Of the seven James crosses, three are hermaphrodites and four females. One of the hermaphrodites is the dark type and very similar to James in fruit quality, while the other six seedlings are of the light type, bearing light fruit. The two light hermaphrodites are much like James in habit, but light-fruited. We thus have not only a hermaphroditic equivalent for James in the dark seedling, but a new type which can be described as a hermaphroditic, light-fruited combination of James and Scuppernong. Of the five self-pollinated seedlings of $\mathrm{H} 2$, all are of the light type, all hermaphrodites, all markedly self-fertile, and all very similar to the parent.

In 1913 sufficient bloom was produced on $\mathrm{H} 2$ to pollinate the leading varieties and some of our best female seedlings. The object of this work was to produce hermaphrodites so nearly resembling the present leading varieties in fruit qualities as to permit substitution, and also to produce hermaphroditic combinations between the standard variety types. During the season of 1916 the seedlings resulting from this 1913 work began fruiting, and the results, while not all that might be desired, are very encouraging. In addition to some new fruittype seedlings having the hermaphroditic bloom character, we apparently have now what might be characterized 
as James, Scuppernong, Thomas, Eden, and Flowers hermaphrodites. However, as these seedlings are only beginning to fruit, this statement is subject to modification. A full test may show the necessity of working into or toward the different standard varietal types through another generation before practically identical hermaphrodites may be available as substitutes for the present standard female sorts. The following table shows the hermaphroditic results (tabulated June 30, 1916) from crosses in which $\mathrm{H} 2$ figured in 1912 and 1913 breeding work.

will be hermaphrodites. These seedlings are chiefly of the third generation, being progeny of hermaphrodite seedlings of $\mathrm{H} 1$ and $\mathrm{H} 2$ parentage. So far, while it has been possible to self-pollinate $\mathrm{H} 1$ and $\mathrm{H} 2$, it has been impossible to cross them directly.

\section{Increase of Productiveness}

Increased productiveness is a leading result secured by the Department in its intercrossing work. This has been accomplished in three different ways.

First, it has been possible to gradually increase the standard of productiveness by selecting among the thousands of seedlings those which give evidence of

In 1914 a considerable number of

TABLE 1.-Hermaphroditic Restults from H2 in 1912 and 1913 Breeding Work, Willard, N. C.

\begin{tabular}{|c|c|c|c|c|c|c|}
\hline Year & $\begin{array}{c}\text { Parentage } \\
\text { (pollen parent stated last) }\end{array}$ & $\begin{array}{c}\text { Total } \\
\text { number } \\
\text { seedlings }\end{array}$ & $\begin{array}{l}\text { Number } \\
\text { hermaph- } \\
\text { rodites }\end{array}$ & $\begin{array}{l}\text { Number } \\
\text { female }\end{array}$ & $\begin{array}{l}\text { Number } \\
\text { male }\end{array}$ & $\begin{array}{c}\text { Number } \\
\text { not yet } \\
\text { tested }\end{array}$ \\
\hline \multirow[t]{2}{*}{1913} & \multirow[t]{2}{*}{ 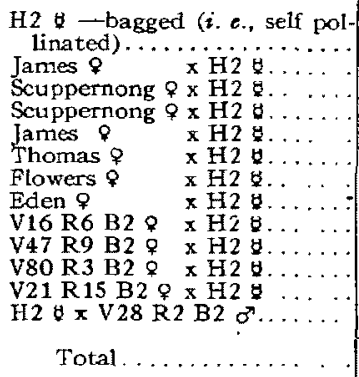 } & $\begin{array}{r}5 \\
7 \\
1 \\
13 \\
16 \\
15 \\
13 \\
27 \\
23 \\
2 \\
2 \\
1 \\
8\end{array}$ & $\begin{array}{r}5 \\
3 \\
\ldots \\
4 \\
7 \\
4 \\
5 \\
14 \\
14 \\
1 \\
1 \\
\ldots \\
1\end{array} \cdots$ & 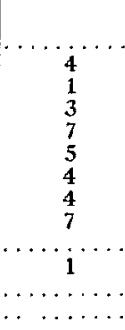 & 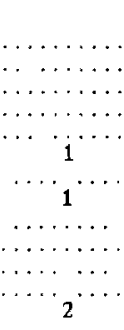 & $\begin{array}{c}6 \\
2 \\
5 \\
4 \\
8 \\
2 \\
1 \\
\ldots \\
1 \\
5\end{array}$ \\
\hline & & 133 & 59 & 36 & 4 & 34 \\
\hline
\end{tabular}

crosses were made using $\mathrm{H} 2, \mathrm{H} 1$, and the better hermaphroditic progeny of H1. Additional work was done in 1915, but the resulting progeny have not yet bloomed. To date, ${ }^{\mathrm{s}}$ in addition to the two original true hermaphrodites and plants propagated from them by cuttings. the Department has produced ninety tested hermaphrodites, fifty-nine tested females, and five tested males from crosses in which $\mathrm{H} 1$ and $\mathrm{H} 2$ have figured. In addition, there are 1,029 seedlings of hermaphroditic parentage in the breeding blocks of the experiment vineyard still untested. It is expected that not less than 50 per cent of these highest productiveness due to profuse- ness of bloom, vigor of growth, resistance to diseases and insects, etc., and then using these as parents of succeeding generations. To make this increase effective merely requires the introduction and substitution of the better new varieties for the present standard commercial sorts.

Second, increased productiveness has been gained by producing the new selffertile hermaphroditic type of Muscadine grape having large clusters, self-fertility, and fruitfulness, to take the place of female varieties and of nonfruiting male vines serving as pollenizers for female varieties. Owing to the selffertility of the hermaphrodites they

\footnotetext{
This manuscript was prepared in November, 1916.
} 


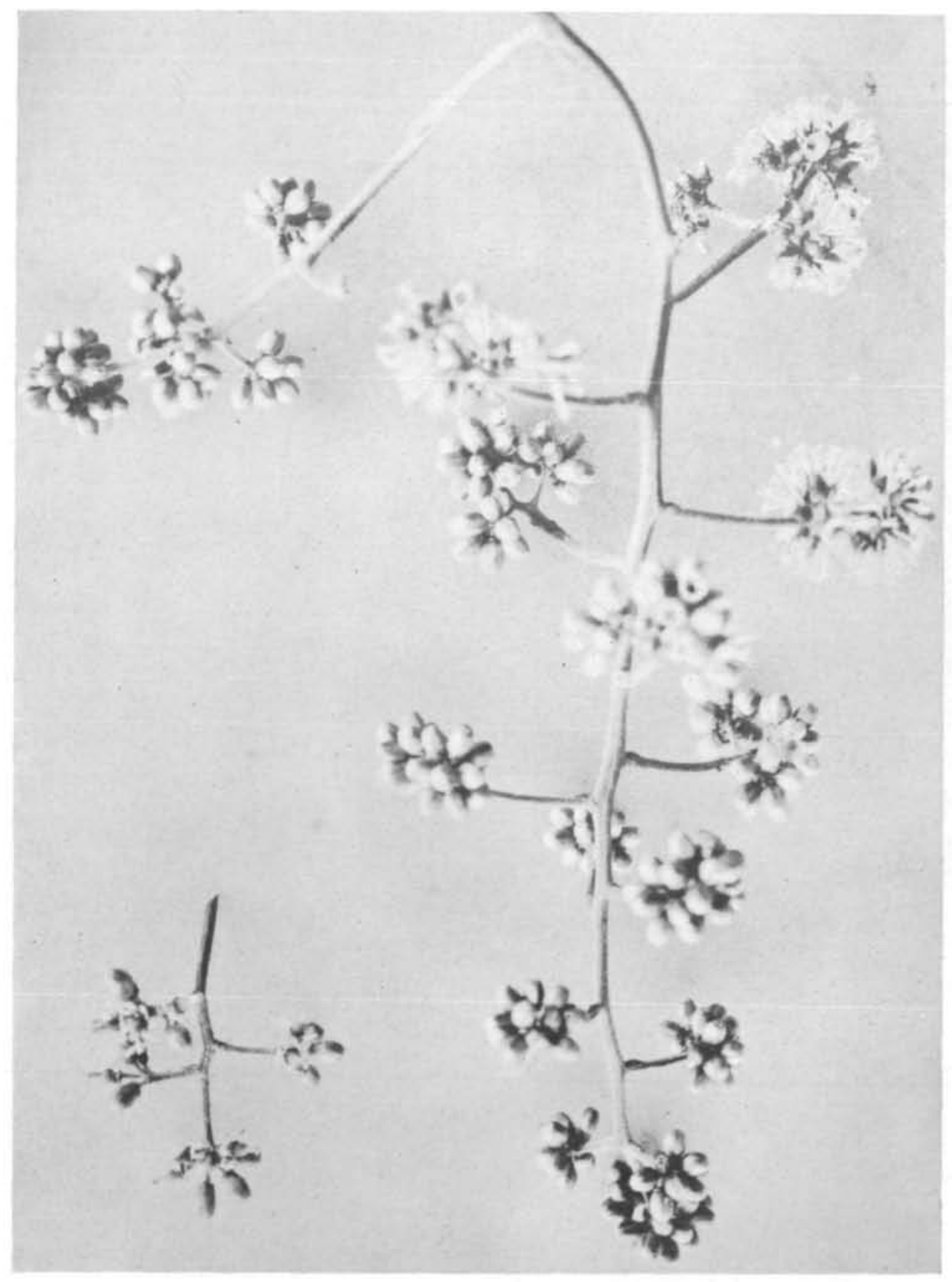

\section{STANDARD AND IMPROVED GRAPE CLUSTERS}

The small bloom cluster in the lower left-hand corner is typical of Scuppernong, the most widely grown variety of Muscadine grape. It bears only a few berries. The large cluster is typical of one of the improved hermaphrodites which the U. S. Department of Agriculture has produced as the result of many years of careful plant-breeding. It excels not only in size, but in almost every other characteristic. Photograph about one and one-half times natural size. (Fig. 15.) 
have been found by test to set in bags over $33 \%$ of the bloom buds as berries, while Scuppernong, the most extensively planted commercial variety, sets naturally less than $10 \%$ of its buds as berries.

Third, by breeding for increased size of bloom cluster it has been possible not only to secure larger fruit clusters (a breeding object), but also increased productiveness. Large bloom clusters result in more perfect cross pollination and the size of bloom cluster is not necessarily in inverse ratio to profuseness of bloom cluster. The number of bloom clusters produced by a vine is ordinarily determined by its general vegetative condition, and little influenced by: the size of the individual bloom cluster. Varieties with large bloom clusters secure better cross pollination and therefore are more fruitful. As the pollen-bearing insect is attracted to the flower by its odor, ${ }^{\circ}$ a large bloom cluster has greater attracting power than a small one, and when the cluster is once found, all open blossoms are pollinated, whereas if this number of open blossoms is found on two clusters the insect might fail to visit one of them. Again, the large bloom cluster, in addition to having more buds open at a time, blooms over a period of two to three days and is therefore much more likely to have sufficient buds to produce a normal cluster open under favorable weather conditions. One illustration of the way these facts have been used in the Department's work seems warranted.

Among the fruiting varieties of Muscadine grapes Scuppernong is the oldest and the leading commercial sort. Its commercial value lies in its good lightcolored fruit, and Scuppernong grapes have sold repeatedly to winemakers at good prices when dark-fruited varieties were not in demand. Still it can be emphatically stated that Scuppernong is one of the most unproductive varieties grown. An eight-year record (19041911) in a well-kept eastern North Carolina vineyard consisting of approxi- mately 5 acres each of James and Scuppernong revealed that James yielded each year approximately twice as much fruit per acre as Scuppernong. Similar results have been repeatedly noted since. A prime reason for the relative lack of productiveness in Scuppernong has been shown by our pollination experiments to be its very small bloom cluster, which reduces the chances for cross-pollination by insects. The following data collected in connection with pollination studies will emphasize the bearing of size of bloom cluster on productiveness of Scuppernong and other commercial varieties. These data represent the averages of a very large number of individual observations during four seasons.

\begin{tabular}{l|c|c|c}
\hline Variety & $\begin{array}{c}\text { Average } \\
\text { number } \\
\text { of buds } \\
\text { per bloom } \\
\text { cluster }\end{array}$ & $\begin{array}{c}\text { Average } \\
\text { number of } \\
\text { berries per } \\
\text { ripe fruit } \\
\text { cluster }\end{array}$ & $\begin{array}{c}\text { Percentage } \\
\text { of buds } \\
\text { setting as } \\
\text { berries } \\
\text { under } \\
\text { natural } \\
\text { conditions }\end{array}$ \\
\hline Scuppernong & 23.8 & 2.5 & $\begin{array}{r}4.64 \\
\text { James.... }\end{array}$ \\
Thomas... & $\mathbf{2 8 . 0}$ & 4.7 & 13.36 \\
Flowers.... & 40.3 & 5.4 & 16.32 \\
15.10 \\
\hline
\end{tabular}

The correlation shown in this table between size of flower cluster and natural productiveness is most striking. Working on the hypotheses suggested by such data as these, the Department has produced by intercrossing and selection many large-clustered seedlings of the Scuppernong type. A number of these having bloom clusters of 35 to $\mathbf{5 0}$ buds, with apparently correlated productiveness, are now being further tested with a view to determining which combine the greatest productiveness with high fruit quality. Thus we have succeeded in improving the productiveness of this most important commercial type while maintaining its distinctive characters. 


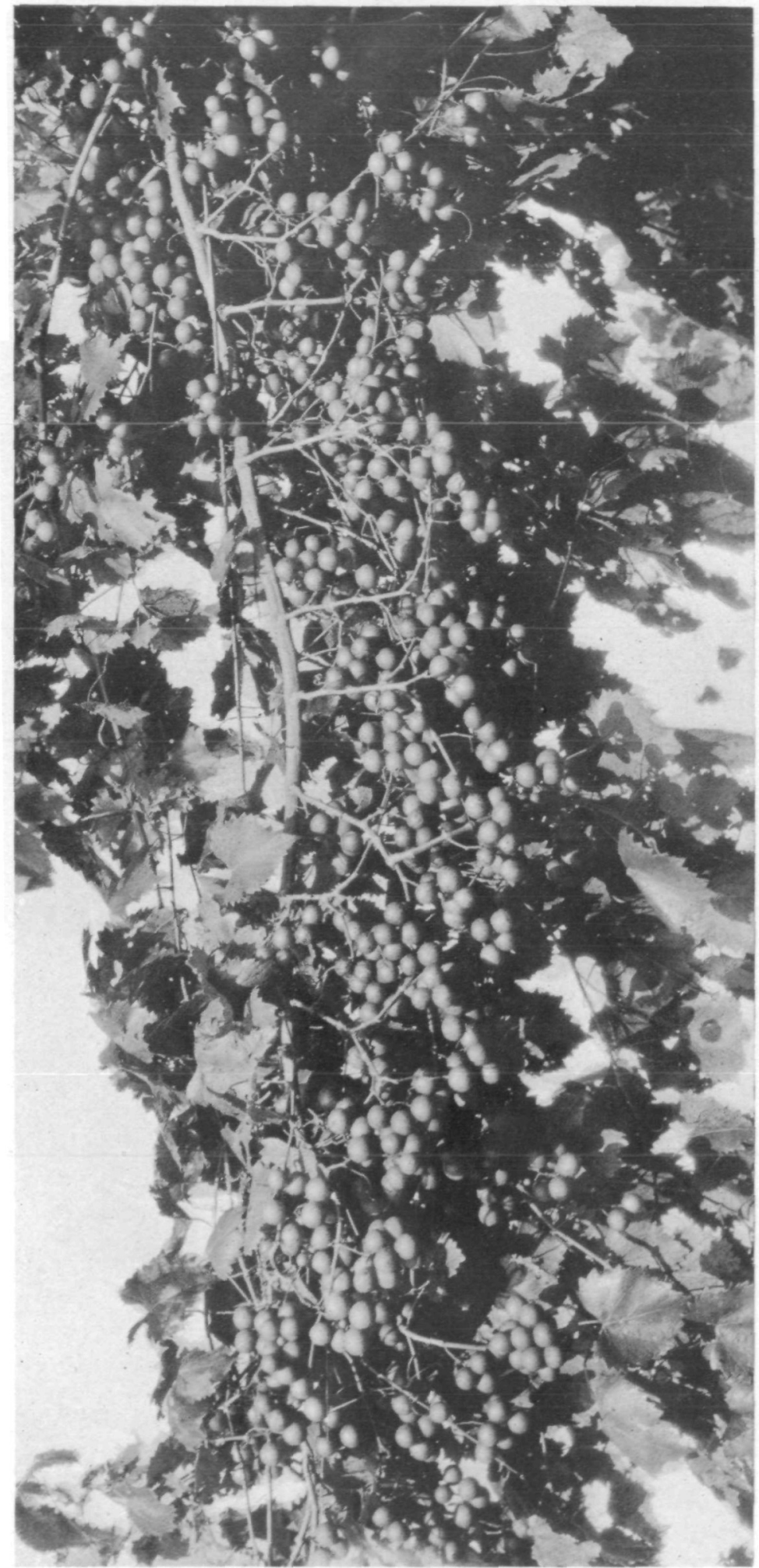

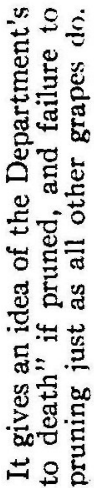

(2)

要

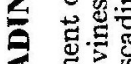

ड

可和

$\sum 气$

is

$>D$ 焉

단 론

촐

$>$ דृ

曐范

Z

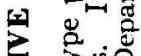

릴

论

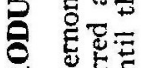

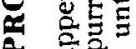

$<40$

눙

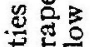

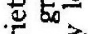

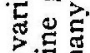

氖

$4 \underbrace{\circ}$

㫜

ธ

E

范岂

包政

总总总 


\section{Increase in Sive of Fruit Cluster}

The success of our efforts to increase the size of fruit cluster by interctossing emphasizes how easy it sometimes is, in plant-breeding, to get combined improvement along several lines, provided these are not antagonistic. The efforts just described to increase productiveness by increasing the size of flower cluster necessarily resulted also in increasing the size of fruit cluster. Again, the transformation of the large male-type bloom into a perfect hermaphrodite bloom has resulted in increasing the size of fruit cluster. A third way in which intercrossing has resulted in increased size of fruit cluster is through the pollination of small-clustered varieties with pollen from the largestclustered male seedling in groups of ssedlings descended from the largestclustered fruiting varieties.

While a considerable increase in size of fruit cluster has been obtained by intercrossing and selection among resulting seedlings, the greatest progress along this line is to be expected from hybridizing with the large-clustered species of Euvitis.

\section{Better Berry Adherence}

From a commercial standpoint, our improvement of the adherence of berry to pedicel by intercrossing is of great importance, since it makes possible the shipping of desirable varieties to distant markets. The standard Muscadine table varieties can not be successfully shipped, because the berries tend to shatter from the pedicels and in doing so the skin frequently breaks at the point of attachment, allowing juice to exude. This juice coats the berries, making them unattractive, sticky, and fermenty. Certain other varieties too coarse for table use and therefore undesirable for shipping, notably Flowers, have excellent berry adherence owing to full development of the fibrovascular bundles connecting the berry with the pedicel. By using male seedlings of Flowers and similar varieties in crosses with Scuppernong, Thomas, and other high-quality varieties of poor adherence, some desirable new types have been secured which combine quality and adherence.

\section{Increased Sugar and Decreased Acid Content}

The principal means used of reducing acid content has been to use parents and select offspring having a minimum of pulp juice and a maximum of socalled free-run juice, $i, e$., the juice between skin and pulp of berry, as most of the acid content of the total juice of Muscadine and other native grapes occurs within the pulp. Sugar content is being increased by using such parents as Latham, Thomas, and Mish. A seedling of Latham parentage represents the greatest advancement in sugar content so far secured, but unfortunately has very small clusters. It is confidently believed that one or two more seedling generations will yield marked results in the effort to increase sweetness and reduce acidity. In this direction, however, greatest results are to be expected from hybridization with $V$. vinifera, the European grape.

\section{Improved Pulp Quality}

A number of seedlings of different parentages have been selected as having improved pulp qualities (smoothness, softness, and free liberation of seed.) In one lot of seedlings, however, the improvement has been especially marked. Among the first seedlings produced, one female seedling was selected as being exceptionally good because it combined with light-colored fruit and excellent berry adherence a remarkably melting pulp. In fact, there was no true pulp, the berries being merely globules of fruit juice. The juice, however, seemed a little too high in acid, and efforts have since been made to increase the sugar of this type while maintaining the desirable pulp and other qualities. A male seedling of the same cross as this exceptional one just described has invariably been found to impart the melting pulp character to its offspring. As a result we now have a considerable collection of melting-pulp seedlings of diverse parentage. These frited for the first time in 1916 and will therefore require 


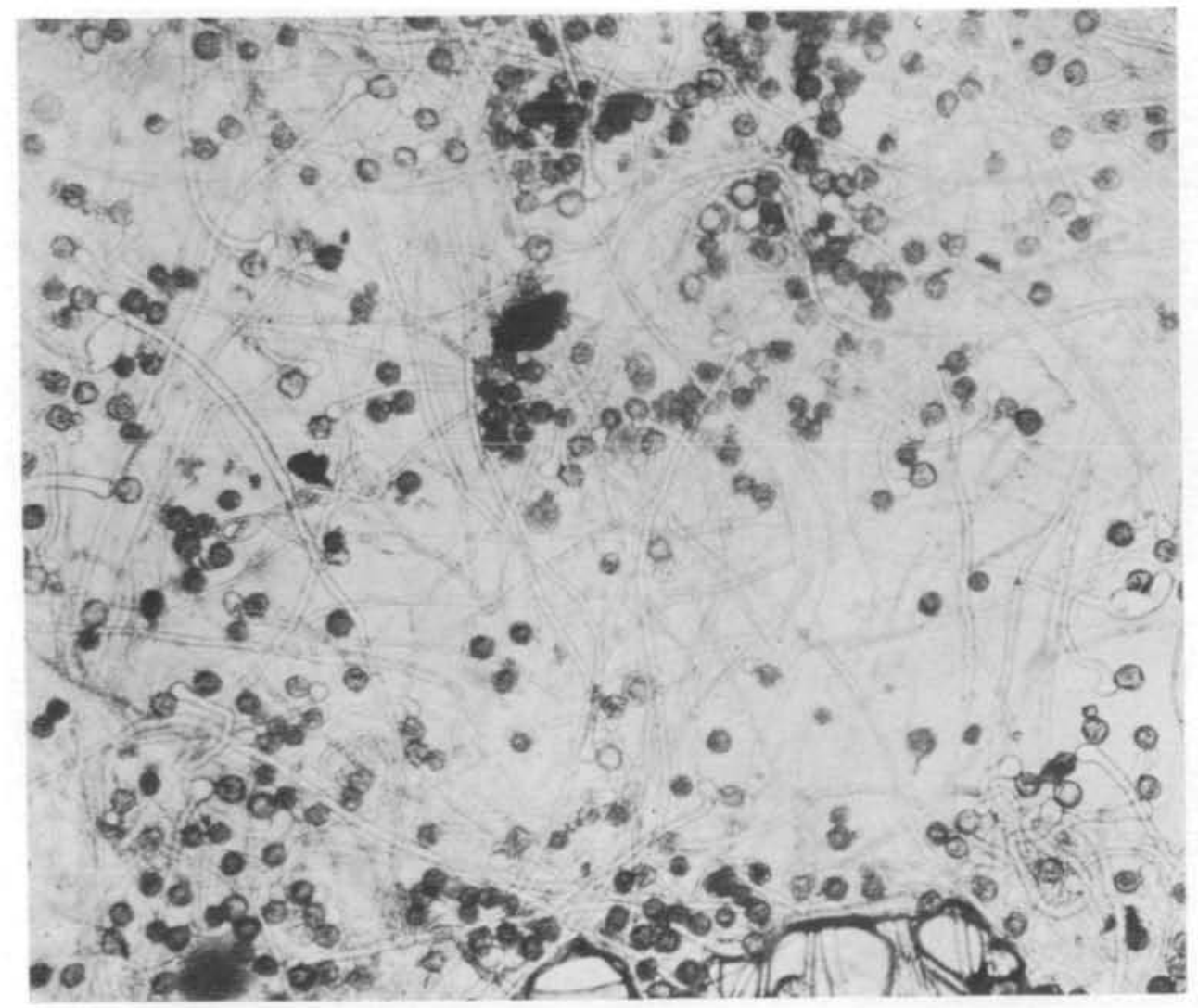

\section{VIGOROUS, GERMINATED POLLEN OF THE WINCHELL GRAPE}

Each of the large dots in the above photomicrograph is a pollen grain. Most of them have germinated in a sugar-gelatin solution, and sent out long pollen tubes. Normally, this pollen tube grows into the ovary, after the pollen has fallen on a fruit-bearing flower, and down the tube the nucleus of the pollen-grain slips to unite with the nucleus of the ovule, thus setting in motion the machinery that will lead to the production of a grape-seed. The photograph, made at Willard, N. C., shows the condition of pollen as it was received by mail from Vineland, N. J. One of the chief factors in successful hybridization of the Muscadine grape has been the use of vigorous pollen. (Fig. 17.)

more testing before their full value can be determined. They are very promising.

\section{Decreased Size of Seed.}

Little reduction has been secured in the size of seed, but this character is considered of less importance than others, especially since the sizes of seed and berry are generally correlated.

\section{Thinner Skin of Berries}

Some reduction of the thickness of berry skin has been gained by intercrossing, especially with the variety Eden. A group of seedlings descended from Eden and James parentage is deserving of special mention here because of the uniform combination of good flavor and quality with thin skin, large berry and cluster, and good adherence. In this lot of seedlings some very promising light- and dark-fruited commercial types are to be found.

\section{Uniform Ripening}

Uniformity of fruit ripening seems to be dependent as much, on the weather at blooming time as on inherent varietal character. However, by working away from the everbearing trait of $V$. munsoniana and breeding 
for large clusters, a little progress is to be expected. Most varieties ripen with sufficient uniformity if the weather is normal at blooming time.

\section{RESULTS FRCM HYBRIDIZING}

So far the results from hybridization work are mainly in technique. The Muscadine grapes are so distinct and uncongenial to the other species of the grape family that hybridization is exceedingly difficult-so difficult, in fact, that the production of hybrids between $V$. roundifolia and Eurvilis species is considered an important result worthy of reporting. even though the hybrids have not yet fruited.

The difficulties to be encountered can be inferred from the experience of those who have given the matter most attention. J. Van Buren, of Clarksville, Ga., working prior to 1868 , failed completely in the attempt. Dr. Peter Wylje, of Chester, S. C., working about the same time as Van Buren, produced several supposed Scuppernong hybrids which were lost to horticulture owing to a series of misfortunes, including the killing frost of April, 1s72. T. V. Munson, of Denison, Tex., produced a few varieties which though predominantly Muscadine in character are supposed to be bybrids with $V$. lincecuniii. Only four or five years ago a prominent State horticulturist made the statement that it was impossible to secure $V$. rotundifolia $\times V$. vinifera hybrids. After two years' effort to produce hybrids of the Muscadinia and Euvitis species the North Carolina experiment station reported, in Technical Bulletin No. 10, complete failure with the exception of one weak plant, which was described when three years old as "still alive." A number of amateurs to whom we have sent pollen have all reported failure. The efforts of the U.S. Department of Agriculture were attended by failure until methods had been perfected and information regarding congeniality obtained. Since then, in addition to producing hybrids with various vative grape species, the Department has produced the first known hybrids between $V$. rolundifolia and the European grapes, V. vinifera.
The Department's furst efforts in this field. in 1911, resulted in complete failure. The next year one supposed hybrid was secured, a cross of Eden $?$ and Flame Tokay $0^{x}$, which has now fruited two years. While it is distinct from other Muscadine seedlings of Eden parentage, it is predominantly Muscadine in character and shows no resemblance to Flame Tokay except in the leaves. From the 1913 breeding work, twenty-two hybrids were secured, but only eight of these were living at the end of the first season in the vineyard. The others had succumbed to disease and inherent weakness. Of these eight seedlings, seven are of Olivette de Vendemain parentage and the result of one crossing operation. The other is the result of pollinating Scuppernong with Winchell. These seedlings have not yet fruited, but they should do so in the season of 1917 . The Scuppernong \& $\times$ Winchell ${ }^{n}$ seedling is the only hybrid we have sccured of Scuppernong parentage. It resembles Winchell more than Scuppernong, though from a Scuppernong seed. It is undoubtedly a true hybrid. The Olivette de Vendemain hybrids are variable in vigor and characters, some being vigorous and others weak; some are more Vinifera in type and others more Muscadine, but all are undoubtedly true hybrids. From the 1914 breeding work a considerable number of seeds was secured, but many of these failed to germinate. However, the following true hybrids were propagated and are now growing at Willard, N. C.:

2 seedlings of Eden $x$ Maraville de Malaga

1 seedling, Thomas $x$ Rodites

3 seedlings, Thomas $x$ Carignane

1 seedling, Thomas $\times$ Noah

1 seedling, V16 R6 B2 x Carignanc

3 seedlings, V17 R6 B2 $\times$ Terret Monstre

In 1915 much greater hybridization success was had. A large collection of seeds was secured and though many of these failed to germinate, seventy true hybrids have been propagated. The following Euvitis varieties are represented in the parentage of these hybrids: 


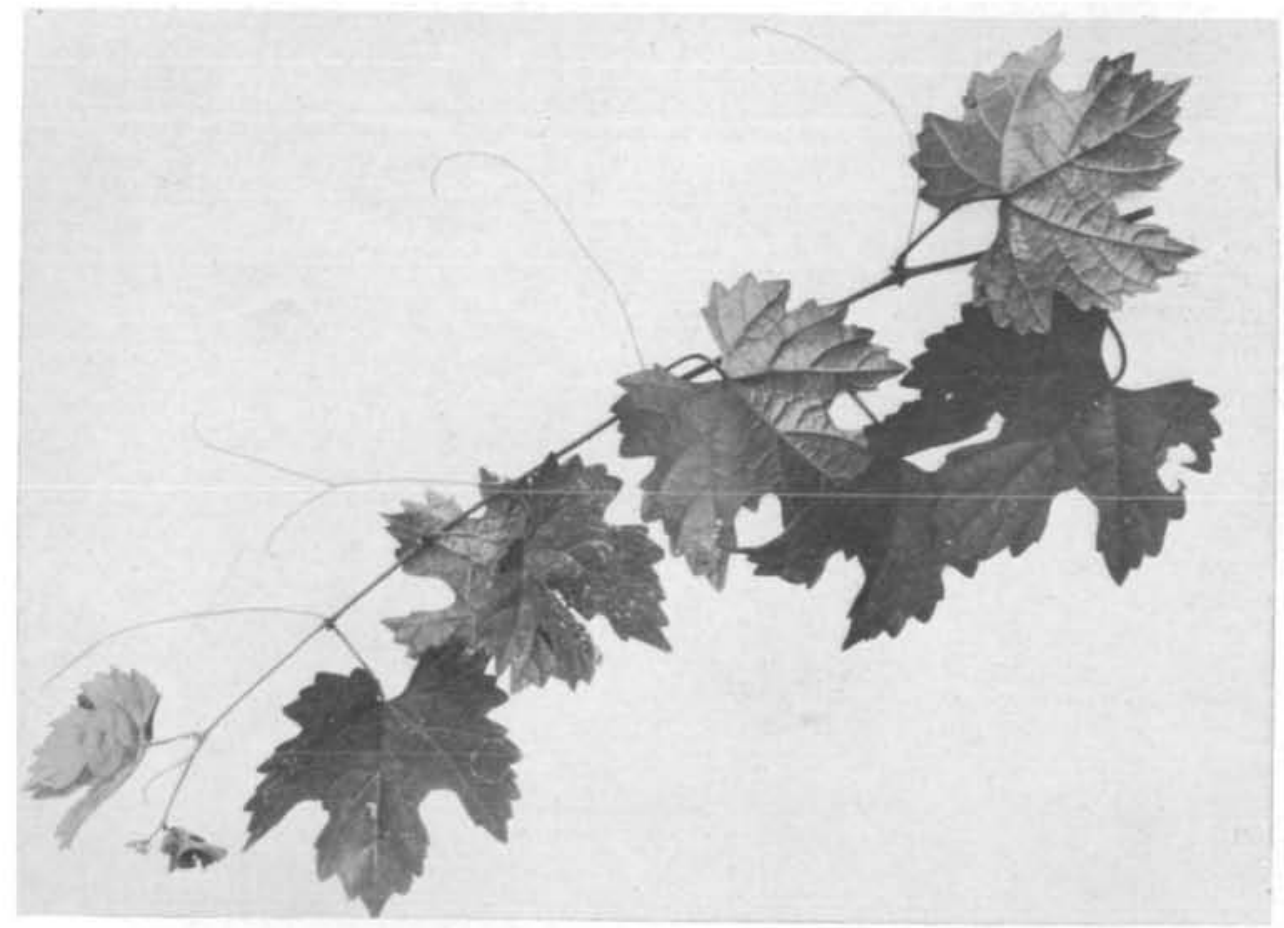

\section{AUTHENTIC HYBRID BETWEEN EUROPEAN AND MUSCADINE GRAPE}

It is so difficult to hybridize Muscadine grapes with European grapes that doubt has often been cast on the genuineness of some of the alleged hybrids. This photograph shows that there can be no doubt about the hybrid nature of those secured by the U. S. Department of Agriculture. The hybrid shows its rolundifolia parentage by simple tendrils, leaf texture, and stem, and its vinifera parentage by forked tendrils, leaf lobes and variable size of leafserrations. Other characters are more or less intermediate. (Fig. 18.)

$\begin{array}{ll}\text { Muscat of Alexandria } & \text { Huasco } \\ \text { Calabrian } & \text { Winchell } \\ \text { Ferrara } & \text { Goethe } \\ \text { Rodites } & \text { Brilliant } \\ \text { Semillon } & \text { Catawba } \\ \text { White Hanepoot } & \text { Iona } \\ \text { Prune de Cazouls } & \text { Ives }\end{array}$

In 1916 a still larger crop of hybrid seeds was secured from breeding work, and is now being grown.

The Department's success in producing Muscadine-Euvitis hybirds is attributable to the perfecting of methods, the use of varieties of greatest congeniality, and the selection of healthy, vigorous vines as parents. Of the commercial varieties of Muscadines, Thomas seems most congenial to Euvitis pollen. A number of the Department's seedling varieties, however, are even more readily hybridized. Certain Euvitis pollens can be more successfully used than others. These lines of con- geniality have been established by experience. In hybridizing, only Muscadines have been used as the female parent; because of their dioeciousness, and because Euvitis pollen can be shipped more successfully than Muscadine pollen. $V$. vinifera pollen has been collected in the Department's experiment vineyards at Oakville and Fresno, Cal., by associates and mailed to Willard, N. C., where it was used in hybridization work after testing to prove its viability. Other Euvitis pollens have been collected at the Department's experiment vineyard at Vineland, N. J., and mailed to Willard for use.

While the hybrids have not yet fruited, it is an important result of breeding work to be able to say that Muscadinia x Euvitis hybrids are being secured in quantity. The hybridity is conclusively proved by their possession 
of botanical characters of both Muscadinia and Euvitis as, for example, in the case of the tendrils. The Muscadinia species always have simple tendrils and the Euvitis always forked tendrils, while the hybrids generally have simple and forked tendrils on the same shoot. In like manner, the hybirds have both continuous and discontinuous pith, etc. It is expected that the first hybrids will leave much to be desired, but in a large collection a few valuable individuals may be found which, when again crossed with the best Muscadine or Euvitis varieties, will yield satisfactory results.

While improvement is expected from the Muscadine hybrids with native grape species, the greatest results are expected from the hybrids with the European grape, $V$. vinifera, because the latter varieties are strong in those characters in which the Muscadines are deficient, and weak only in the characters well developed in the Muscadines. For example, $V$. vinifera is very high in sugar but low in acid content, while the Muscadines are high in acid content but low in sugar. The native American Euvitis species, while having a higher sugar content generally than the Muscadines, are like the latter in their high acid content.

\section{SUMMARY}

The Muscadine grape breeding of the U. S. Department of Agriculture ${ }^{7}$ is centered in a coōperative experiment vineyard located on the North Carolina State Department of Agriculture's Test Farm, Willard, N. C. Here pollination, culture, handling, marketing, and utilization problems have also been under investigation. Special emphasis has been given to pruning, training, and pollination studies, but the breeding investigations have occupied first place.

It is believed that with the achievment of the results from breeding work for which the Department is striving, together with the development of improved methods of growing, handling, and utilizing the fruit, the Muscadine grape industry will take a leading position among the fruit industries of the South and will afford a profitable means of utilizing a portion of the vast areas of cut-over pine lands of the Southeast.

\section{Peculiarities of Conformation in Singers}

As the conformation of those parts of the head used for singing is inherited, it is natural to suppose that singing ability is largely dependent on heredity. Dr, Irving Wilson Voorhees, who writes in the July issue of Medical Review of Reviews, gives some details about the peculiarities of conformation which show why training alone cannot produce a singer.

"I have studied the noses and throats of several of the great singers," he says. "and in each and every case can say that there was something remarkable about the formation of the nasal chambers or vocal cords or general muscular development of the chest. It is not always possible to tell what a voice is by a physical examination, but many times one can make a fair guess at it. The tenor's vocal cords, for instance, are likely to be short and thick; the basso's, long and flat. Like differences hold good for female voices. I am told by a physician who has examined Caruso that he has a broad roof to the mouth, a large nasopharynx, very roomy nasal resonators, and short, thick vocal cords with knifelike edge."

7 The progress of the Department's work with the Mnscadine grapes has been reported in the reports of the Chief of the Bureau of Plant Industry and in the following bulletins:

Bulleitin 273, Bureau of Plant Industry, The Muscadine Grapes.

Farmers' Bulletin 709, U. S. Department of Agriculture, The Muscadine Grapes.

Farmers' Bulletin 758, U. S. Department of Agriculture, Muscadine Grape Sirup.

Farmers Bulletin 859, U. S. Department of Agriculture, Home Uses for Muscadine Grapes. 